\title{
Wpływ tlenu resztkowego w gazie formującym na wybrane właściwości grani złącza stali 304L spawanego TIG orbitalnie
}

\author{
The influence of the residual oxygen in the forming gas \\ on selected properties of the $304 \mathrm{~L}$ steel root joint \\ welded by orbital TIG
}

\section{Streszczenie}

W pracy opisano wpływ stężenia tlenu resztkowego w gazie formującym na wybrane właściwości grani spoiny czołowej stali 304L wykonanej metodą spawania orbitalnego TIG. Przeprowadzono próby spawania z gazem formującym $\mathrm{Ar}$ z zawartością tlenu na poziomie 6 ppm oraz 500 ppm. Uzyskane złącza porównano pod względem budowy strukturalnej oraz rozkładów twardości.

Słowa kluczowe: spawanie orbitalne TIG; stal 304L; utlenianie grani

\begin{abstract}
This paper describes the effect of the concentration of residual oxygen in the forming gas on selected properties of the root area in butt weld of steel 304L made by orbital TIG welding method. Welding tests were conducted in Argonium forming gas with oxygen content of $6 \mathrm{ppm}$ and $500 \mathrm{ppm}$. The resulting joints were compared in terms of structural composition, geometry and hardness distribution.
\end{abstract}

Keywords: orbital TIG welding; steel 304L; oxidation of root

\section{Wstęp}

Najpopularniejszą metodą łączenia rurociągów ze stali wysokostopowej jest metoda TIG (ang. Tungsten Inert Gas), zwana też GTAW (ang. Gas Tungsten Arc Welding). Pomimo trudności z jej automatyzacją, na potrzeby wykonywania połączeń doczołowych rur opracowano odmianę orbitalną TIG. Jest to odpowiedź na ciągle rosnące wymagania jakościowe. Nie bez znaczenia pozostaje kwestia oczekiwania wyższej wydajności spawania niż podczas spawania ręcznego oraz prognozowanego deficytu wysoko wykwalifikowanych spawaczy. Wprowadzenie automatyzacji dostarcza jednak wielu trudności dotyczących, chociażby zapewnienia stałych właściwości "styku" przygotowanego złącza, na zmianę których, spawacz operujący ręcznie reaguje odpowiednio w czasie rzeczywistym. Spawanie orbitalne jest procesem zautomatyzowanym, realizowanym za pośrednictwem specjalnie przystosowanych do tego celu głowic spawalniczych przemieszczających się względem nieruchomego złącza. Technika spawania orbitalnego jest wykorzystywana m.in. do wykonywania rurociągów, wężownic i innych konstrukcji rurowych. W technice spawania orbitalnego mogą być wykorzystywane różne metody spawania (najczęściej TIG). W przypadku elementów rurowych o grubości ścianki do $2 \mathrm{~mm}$ proces spawania może być prowadzony bez dodatku spoiwa, podczas spawania elementów

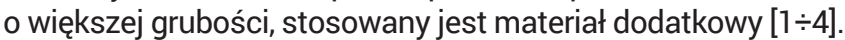

Celem pracy jest wskazanie wpływu obecność tlenu w gazie formującym na właściwości grani. Istnieją co najmniej dwa powody, dla których stosuje się ochronę grani spoiny podczas spawania GTAW. Po pierwsze, jest to wspomniana wcześniej ochrona przed utlenianiem. Po drugie, to uzyskanie grani gładkiej, o łagodnym kształcie. Działanie prowadzące do takiego efektu jest nazywane formowaniem grani. Tym sposobem można uniknąć kosztownego czyszczenia wnętrza wykonanej instalacji rurowej. Ze względu na wysoką cenę czysty argon powinien być stosowany tylko w uzasadnionych przypadkach. Tańsza od argonu jest mieszanka azotu z wodorem, lecz podwyższa ryzyko wystąpienia pęknięć, tym bardziej, jeśli stal wykazuje skłonność do utwardzenia w SWC. W związku z tym, gazem zalecanym i najczęściej stosowanym do ochrony lica oraz grani podczas spawania metodą TIG austenitycznej stali Cr-Ni jest argon lub jego mieszanka z wodorem (do około 5\%). Przed przystąpieniem do spawania rurociągu należy przepłukać wnętrze rury gazem formującym. Natężenie przepływu gazu płuczącego wynosi od ok. 5 do $12 \mathrm{l} / \mathrm{min}$ i jest zależne od średnicy rury. Po osiągnięciu wymaganej czystości gazu formującego w rurociągu należy zmniejszyć przepływ do wartości ok. $2 \mathrm{l} / \mathrm{min}$. Zabezpiecza to przed utratą nadciśnienia wewnątrz rurociągu oraz zasysaniem do jego wnętrza powietrza.

Mgr inż. Marcin Drabarz - MDTechnology, dr hab. inż. Tomasz Chmielewski, prof. PW - Politechnika Warszawska.

Autor korespondencyjny/Corresponding author. t.chmielewski@wip.pw.edu.pl 
Natężenie przepływu nie powinno być zbyt duże, ponieważ podczas zamykania obwodu spoiny może to powodować powstanie zbyt dużego ciśnienia, a w konsekwencji wklęsłości grani lub nawet uniemożliwienie jej zamknięcia. Bezpośrednio po spawaniu należy utrzymać niewielki nadmuch gazu formującego, aż do momentu, gdy temperatura złącza osiągnie wartość poniżej $200^{\circ} \mathrm{C}$, tak aby nie powstały przebarwienia w grani spoiny i obszarach do niej przylegających. Oprócz analizowanych skutków nadmiernego stężenia tlenu w gazie formującym, równie istotnym jest uwrażliwienie na korozję i konieczność repasywacji, czego nie dotyczy ten artykuł.

\section{Warunki spawania}

Problem czystości gazu formującego jest istotny, ponieważ w przypadku spawania orbitalnego rur, najczęściej ich spawanie następuje na instalacji, która została już częściowo wstępnie sczepiona. Tak przygotowany do spawania rurociąg jest wypełniany gazem formującym i zwykle tylko w określonych miejscach za pomocą czujnika można określić ilość tlenu resztkowego $\mathrm{w}$ rurociągu. W ramach eksperymentu wykonano złącza próbne na rurach stalowych w gatunku 304L wg AISI (wg EN10088 1.4306; wg DIN X2CrNi19-11) z różnym stężeniem tlenu (6 ppm oraz 500 ppm) $\mathrm{w}$ gazie formującym. Średnica zewnętrzna rury wynosiła $70 \mathrm{~mm}$, grubość ścianki $2 \mathrm{~mm}$. Spawano bez materiału dodatkowego, jako gaz osłonowy i formujący stosowano argon 99,995\% (I1 wg PN-EN ISO 14175). Kąt wierzchołkowy nietopliwej elektrody wolframowej - $30^{\circ}$ (koniec elektrody stępiony), długość łuku 1,5 mm, elektroda zorientowana prostopadle do stycznej i do tworzącej rury.

Na rysunku 1 przedstawiono zestaw parametrów spawania.

Złącze zostało podzielone na 4 sektory rys. 1, każdy z sektorów reprezentuje inną pozycję spawania. Parametry zostały dobrane z bazy danych synergicznego systemu sterowania. Największe natężenie prądu spawania stosowano w sektorze 3, w pozycji pionowej z góry do dołu, co jest związane z grawitacyjnym opadaniem jeziorka ciekłego metalu, w związku z czym potrzebne jest stosunkowo dużo energii

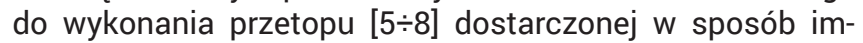
pulsowy. Wartość natężenia prądu spawania dostosowano do warunków spawania w każdym z czterech sektorów. Stosowano impulsowe zasilanie łuku o natężeniu prądu impulsu koło 70A i ok. 30A (z kilkuprocentowymi zmianami w sektorach) natężenie prądu bazowego. Czas trwania obu faz cyklu był równy i wynosił 0,2 s. Prędkość spawania na całym obwodzie jest stała i wynosi $85 \mathrm{~mm} / \mathrm{min}$. Zakładka końca spoiny na jej początek wynosi $20 \%$ długości pierwszego sektora. Natężenie prądu podczas wygaszania łuku wynosiło 3A, a czas 5 s. Bezpośrednio po zakończeniu spawania, jeszcze przez, $30 \mathrm{~s}$. utrzymywany był stały przepływ gazu osłonowego, aby umożliwić wystygnięcie katody i spoiny w gazie obojętnym. Całkowity czas procesu spawania razem z początkowym i końcowym przepływem gazu wynosi 214,5 s., tj. 3,5 min., i jest on około 2 razy krótszy odczasupotrzebnego do ręcznego wykonaniaspawaniaprzez doświadczonego spawacza.

Wykonano próby spawania dla stężenia tlenu resztkowego w gazie formującym w wysokości 6 ppm i 500 ppm. Lico wszystkich wykonanych spoin jest czyste i bez widocznych przebarwień. Podczas spawania, od strony lica spoiny była pełna ochrona gazowa. Elektroda poruszała się w zamkniętej komorze wypełnionej argonem ze stałym przepływem gazu.

Próby spawania wykonano przy użyciu systemu do spawania orbitalnego Orbimat $165 \mathrm{CA}$, opartego na głowicy Orbiweld76S z wodnym chłodzeniem (rys. 2).
304L

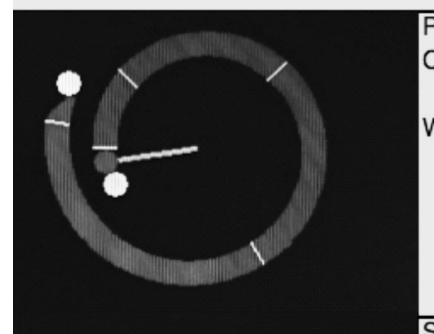

\begin{tabular}{|c|c|}
\hline Prąd zajarzania & ह $\mathrm{A}$ \\
\hline Czas tworzenia jeziorke & $5,0 \mathrm{sec}$. \\
\hline Wstępny przepływ gazı & $15,0 \mathrm{sec}$. \\
\hline Sektor 1 & $0-45^{\circ}$ \\
\hline Cras & $19,40 \mathrm{sec}$. \\
\hline WP Prąd & $74,9 \mathrm{~A}$ \\
\hline NP Prąd & $33,7 \mathrm{~A}$ \\
\hline WP Czas & 0,20 sec. \\
\hline NP Czas & $0,20 \mathrm{sec}$. \\
\hline WP Prędkość & \& mm/mi \\
\hline NP Prędkość & \& $\mathrm{mm} / \mathrm{mi}$ \\
\hline Rampa & $0 \%$ \\
\hline Sektor 2 & $45-135^{\circ}$ \\
\hline Cras & $38,81 \mathrm{sec}$. \\
\hline WP Prąd & $71,9 \mathrm{~A}$ \\
\hline NP Prąd & $32,3 \mathrm{~A}$ \\
\hline WP Czas & $0,20 \mathrm{sec}$. \\
\hline NP Czas & $0,20 \mathrm{sec}$ \\
\hline WP Prędkość & $86 \mathrm{~mm} / \mathrm{mi}$ \\
\hline NP Prędkość & க $\mathrm{mm} / \mathrm{mi}$ \\
\hline Rampa & $20 \%$ \\
\hline Sektor 3 & $135-240^{\circ}$ \\
\hline Cras & $45,28 \mathrm{sec}$. \\
\hline WP Prąd & $76,4 \mathrm{~A}$ \\
\hline NP Prąd & $34,3 \mathrm{~A}$ \\
\hline WP Czas & $0,20 \mathrm{sec}$. \\
\hline NP Czas & $0,20 \mathrm{sec}$. \\
\hline WP Prędkość & க $\mathrm{mm} / \mathrm{mi}$ \\
\hline NP Prędkość & க6 mm/mi \\
\hline Rampa & $20 \%$ \\
\hline Sektor 4 & $240-370^{\circ}$ \\
\hline Cras & $56,06 \mathrm{sec}$ \\
\hline WP Prąd & $73,4 \mathrm{~A}$ \\
\hline NP Prąd & $33,1 \mathrm{~A}$ \\
\hline WP Czas & $0,20 \mathrm{sec}$. \\
\hline NP Czas & $0,20 \mathrm{sec}$. \\
\hline WP Prędkość & க $\mathrm{mm} / \mathrm{mi}$ \\
\hline NP Prędkość & க6 mm/mi \\
\hline Rampa & $20 \%$ \\
\hline Prąd końcowy & $3 \mathrm{~A}$ \\
\hline Wygaszenie & $5,0 \mathrm{sec}$ \\
\hline Przepływ gazu po spaw & $30,0 \mathrm{sec}$ \\
\hline Czas całkowity & $214,5 \mathrm{sec}$. \\
\hline Czas spawania & $169,5 \mathrm{sec}$. \\
\hline
\end{tabular}

Rys. 1. Parametry spawania w poszczególnych sektora 0-370 Fig. 1. Welding parameters in specific sectors $0-370^{\circ}$

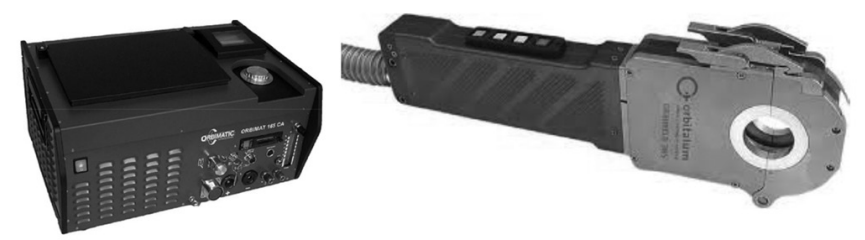

Rys. 2. Źródło prądu Orbimat 165CA i głowica zamknięta Orbiweld 76S Fig. 2. Current source Orbimat 165c and closed head Orbiweld 76S

Wpływ tlenu w gazie osłonowym/formującym na właściwości spoiny jest bardzo istotny.

Podczas procesu spawania stali zawsze należy liczyć się z możliwością utleniania materiału spoiny tzn. oddziaływaniem 
tlenu na jeziorko ciekłego metalu. Intensywność utleniania zależy od składu atmosfery oraz temperatury ośrodka i zawsze zachodzi w przestrzeni łukowej i w kąpieli metalu. Silniej od strony lica i dużo słabiej od strony grani $[5,1]$. Ze względu na konwekcyjny ruch cieczy w kąpieli metalicznej, produkty utleniania mogą docierać głębiej po, powierzchnię.

W orbitalnej odmianie spawania TIG stosowana jest obojętna chemicznie osłona gazowa lica w postaci argonu lub helu. Ma ona za zadanie zapobiegać zachodzeniu niepożądanych reakcji pomiędzy ciekłym stopiwem a otaczającą atmosferą oraz zapobiegać przed utlenianiem elektrody. Stosowana jest także osłona grani w postaci gazu formującego, którym może być argon, hel, azot lub ich domieszki np. z wodorem o udziale do 5\%. Pomimo stosowania ochrony gazowej cząsteczki tlenu mogą przedostać się do obszaru kąpieli metalicznej. Utlenianie może być również spowodowane pośrednio poprzez tlenki znajdujące się na powierzchni materiałów, z których powierzchnię należy oczyścić.

Utlenianiu się podlegają wszystkie składniki stopowe metalu, jednakże w zależności od ich powinowactwa do tlenu, następuje to z różną intensywnością. Tlen powoduje również zwiększenie "rzadkopłynności” jeziorka ciekłego metalu i może powodować wypalenie dodatków stopowych. Przykładowo, w skutek utleniania się ciekłego metalu może nastąpić jego zubożenie w chrom. Obniża to odporność korozyjną stali. $Z$ tego powodu dla typowych austenitycznych stali chromowo-niklowych gat. 304 zawartość tlenu w gazie formującym nie powinna przekraczać 20 ppm. W przypadku stali gat. 316L utrata właściwości antykorozyjnych na skutek tworzenia się tlenków chromu następuje, jeżeli ilość tlenu w gazie osłonowym przekracza 50 ppm [5].

Do pomiaru stężenia tlenu resztkowego zastosowano urządzenie Oxy Integral Oxygen Analyser firmy Orbitec. Zakres pomiarowy tego urządzenia wynosi $5 \div 999$ ppm (part per milion - cząstek tlenu na milion; 1 ppm =0,000001).

Pomiar stężenia tlenu resztkowego oparty jest na czujniku tlenu zbudowanym ze stabilizowanego tlenku cyrkonu. Zasada jego działania oparta jest na prawie Nernsta (W.H. Nernst, 1864-1941). Czujniki te, wykorzystują tlenek cyrkonu

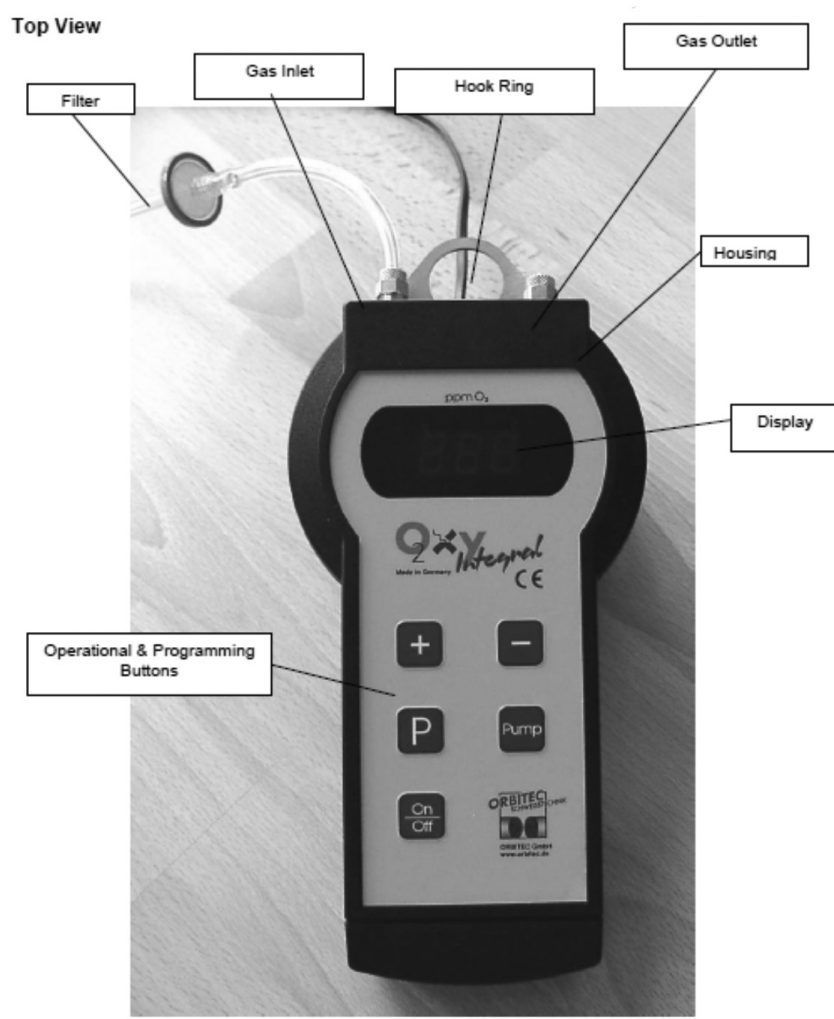

Rys. 3. Miernik tlenu resztkowego w gazie formującym OXY Integral Fig. 3. The tester of the residual oxygen in forming gas OXY Integral jako elektrolit w stanie stałym. Sonda jest pokryta platyną na przeciwległych bokach tworzących elektrody. Tlenek cyrkonu pozwala na migracje jonów tlenu, więc jeśli jest wystawiony na działanie gazów o różnym ciśnieniu parcjalnym, pomiędzy platynowymi elektrodami powstaje napięcie elektromechaniczne. Napięcie to wzrasta logarytmicznie wraz ze spadkiem ilości cząstek tlenu w powietrzu i jest przetwarzane przez zadaną funkcję w procesorze na odpowiedni odczyt tlenu na wyświetlaczu czujnika.

\section{Kryteria akceptacji złącza}

Z powodu wąskiego ściegu od strony grani, należy zwrócić szczególną uwagę, na występowanie pełnego przetopu, a także czy spoina jest symetryczna i czy odpowiednie jest wtopienie w materiał z każdej ze stron. Celem tego jest wykluczenie przyklejenia. Obserwując strukturę złącza na zgładzie metalograficznym, należy wziąć pod uwagę typowe niezgodności spawalnicze, które można uszeregować w sześciu grupach: 1) pęknięcia, 2) pustki (pęcherze gazowe), 3) wtrącenia stałe (np. wolframu, tlenków), 4) brak przetopu i przyklejenie, 5) niezgodności dotyczące kształtu i wymiaru (np. podtopienie, nadlew, nadmierna wypukłość, wyciek czy przesunięcie liniowe).

Kryteria akceptacji niezgodności dotyczące kształtu i wymiaru złączy doczołowych rur przedstawia amerykański standard ASME BPE -2007 wprowadzony przez AWS (ang. American Welding Society) na podstawie którego maksymalne dopuszczalne przesunięcie liniowe, wynosi poniżej $15 \%$ grubości ścianki rury. Dla przeprowadzonych badań na rurze o zakładanej grubości ścianki równej $2 \mathrm{~mm}$ maksymalne dopuszczalne przesunięcie liniowe wynosi $0.3 \mathrm{~mm}$. Zdefiniowane zostało również maksymalne, dopuszczalne wklęśnięcie grani i lica, które wynosi 10\% grubości ścianki, czyli 0,2 mm. oraz maksymalne, dopuszczalne wypuklenie (nadlew), który wynosi 0,38 mm dla lica i 10\% grubości ścianki, czyli 0,2 mm dla grani. Całkowicie niedopuszczalny jest brak przetopu. Akceptowalne jest miejscowe zmniejszenie szerokości spoiny (rys. 4) zarówno od strony lica, jak i grani, jednakże do szerokości, nie mniejszej niż 50\% nominalnej. Dopuszczalne odchyłki spoiny od osi złącza wynoszą $25 \%$ nominalnej szerokości spoiny. Potencjalne przesunięcie osiowe jeziorka ciekłego metalu jest niebezpieczne zwłaszcza od strony grani, w której miejscowo może pojawiać się brak przetopu lub przyklejenie.
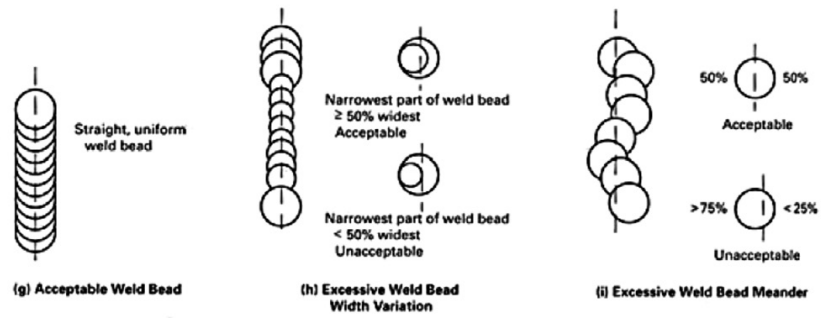

Rys. 4. Kryteria oceny kształtu spoin w doczołowym połączeniu rurowym [9]

Fig. 4. Criteria for evaluation the shape of the joints in butt pipe connection [9]

Standard ASME BPE-2007 wprowadza również klasyfikację poprawności złącza na podstawie przebarwień spoiny, jednak odnosi się on do stali 316L o wyższej odporności na wysokotemperaturowe utlenianie niż stosowana w niniejszych badaniach stal 304L.

Podczas kontroli spoiny kolor przebarwień (rys. 5) determinuje jej ocenę. Badania [10] dowodzą, że powyżej numeru 


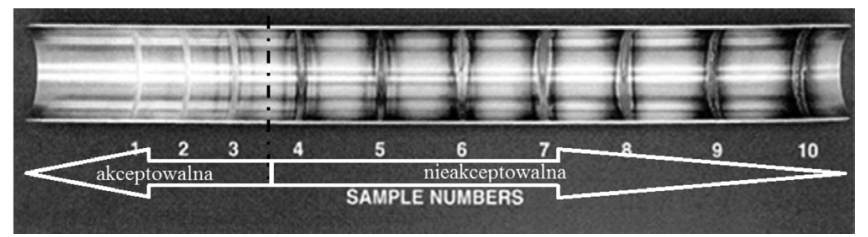

Nr 1 - 10 ppm; nr 2 - 25 ppm; nr 3 - 50 ppm; nr 4 - 100 ppm; nr 5 - 200 ppm; nr 6 - 500 ppm; nr 7 - 1000 ppm; nr 8 - 5000 ppm; nr 9 - 12500 ppm; nr 10 - 25000 ppm.

* W stali 304L są nieznaczące różnice w kolorze odbarwienia w porównaniu do stali typu $316 \mathrm{~L}$, przesunięty jest również próg granicznego stężenie tlenu resztkowego poniżej 25 ppm

Rys. 5. Przebarwienie grani w zależności od ilości tlenu resztkowego w gazie formującym dla stali $316 L^{*}$

Fig. 5. The discoloration of the root $316 \mathrm{~L}$ steel joint depending on the amount of residual oxygen in the forming gas

3, tj. 50 ppm kolor przebarwienia wskazuje na odporność korozyjną spoiny i SWC w austenitycznych stalach chromowoniklowych. Ocena przebarwień jest subiektywna, zależna od oświetlenia oraz fizycznych zdolności postrzegania kolorów przez człowieka. Dlatego też za dopuszczalne należy przyjąć pierwsze dwa przebarwienia - nr 1 i nr 2, w których grań spoiny pozostaje biała lub odbarwiona w sposób nieznaczny. Odporność korozyjną miejsc przebarwionych można poprawić poprzez dodatkową ich pasywację, jednakże jest to proces wystarczający tylko dla grani oznaczony $\mathrm{nr} 3 \mathrm{i} \mathrm{nr} 4$ na rysunku 5. W przypadku spoin nr 5 tj. 200 ppm i wyżej, w celu usunięcia przebarwień można zastosować zabiegi elektrochemicznego czyszczenia lub elektropolerowania, a następnie pasywacji, aby utworzyć warstwę tlenku chromu na powierzchni. Czynności te podwyższają odporności korozyjną stali do wartości takiej, jaką charakteryzuje się materiał przed spawaniem $[9,10]$. Jednak w przypadku wykonywania rurociągów znacznej długości oraz przy małej wartości średnicy zabiegi takie są niezwykle kosztowne, a często praktycznie niewykonalne, co skłania do zachowania podczas spawania właściwie niskiego stężenia tlenu w gazie formującym.

$\mathrm{Na}$ skutek działania tlenu resztkowego w przekroju poprzecznym spoiny, w wyniku spawania powstają zmiany strukturalne. Pojawia się więc wątpliwość, jaki wpływ na wytrzymałość spoiny ma stężenie tlenu resztkowego w gazie formującym podczas spawania oraz czy dopuszczalny będzie zabieg oczyszczenia i pasywacji grani spoiny bez konieczności wycinania oraz wykonania nowego połączenia.

\section{Badania mikrostrukturalne}

Mikrostrukturę spoiny (rys. 5) wykonanej ze stężeniem tlenu 6 ppm w gazie formującym charakteryzują w jej osi ziarna równoosiowe (tzw. strefa kryształów równoosiowych), gdzie ziarna mogą się swobodnie rozrastać. Krystality od linii wtopienia, gdzie zaczyna się zarodkowanie od powierzchni stałej są nieregularne, ponieważ kolejne powstałe dendryty nakładają się tam na siebie, wzajemnie się zniekształcają. Są również skierowane ku środkowi, tzn. rozrastają się w kierunku najłatwiejszym, gdzie mogą zużyć najmniej energii tj. w kierunku odprowadzania ciepła. Jest to tzw. strefa kryształów słupowych. Ślady po krystalizacji spoiny skierowane ku górze, świadczą o odpowiednich proporcjach głębokości do szerokości spoiny. Taka krystalizacja zapobiega przed zamknięciem ciekłego metalu wewnątrz spoiny, przez co uniemożliwia chemiczną niejednorodność [11]. Ponadto widoczne są dwie, niewyraźne linie wtopienie w kolejne zastygnięte jeziorka ciekłego metalu. Główna linia wtopienia w materiał rodzimy jest dość szeroka i nieregularna. Może ona również posiadać podwyższoną zawartość ferrytu $\delta$, co jest charakterystyczne dla spoin, których krystalizacja rozpoczyna się od krystalizacji ferrytu $\delta$. Mechanizm tworzenia się tego obszaru wygląda następująco: (1) na skutek wysokiej temperatury, w pobliżu linii wtopienia rozpoczyna się przemiana $y->\delta$, (najczęściej na istniejących już ziarnach ferrytu $\delta$ ), która postępuje w obszarach o większej zawartości chromu; (2) w czasie szybkiego chłodzenia spoiny obszary te nie nadążają dokonać przemiany powrotnej $\delta->\gamma$, przez co nie uzyskują struktury równowagowej, a co za tym idzie, zawartość ferrytu $\delta$ jest w nich podwyższona [11]. Podwyższona wartość ferrytu powoduje mniejszą odporność na korozję złącza spawanego stali 304L. SWC posiada szerokość około 0,6 mm.

Poniższej przedstawiona została analiza geometryczna wykonanych złączy na podstawie zdjęć metalograficznych próbek pobranych w drugim sektorze spoiny (patrz rys. 1) oraz analiza makroskopowa lica i grani spoiny wraz z oceną powstałych przebarwień. Analizie poddano obszar sektora 2, ponieważ do jego wykonania stosowana jest najwyższa wartość energii liniowej spawania i co wiąże się ze wzrostem powinowactwa chemicznego tlenu do składników stali.

Wykonanie połączenia przy stężeniu tlenu resztkowego w gazie formującym w wysokości 6 ppm pozostawia czystą i białą grań bez przebarwień (rys. 5). Rysunek 6 obrazuje stan złącza spawanego wykonanego ze stężeniem tlenu 500 ppm w gazie formującym. Przy tej wielkości grań spoiny posiada znaczne naloty barwne.

Lico spoiny sektora 2 (rys. 5b) w zasadzie o stałej szerokości $4.8 \mathrm{~mm}$ na całej długości sektora 2. Dopiero podczas przejścia z sektora 2 na 3 następuje zwiększenie szerokości lica. Grań (rys. 5c) o stałej szerokości $2.9 \mathrm{~mm}$, cieńsza niż w sektorze 1, o $0.6 \mathrm{~mm}$.

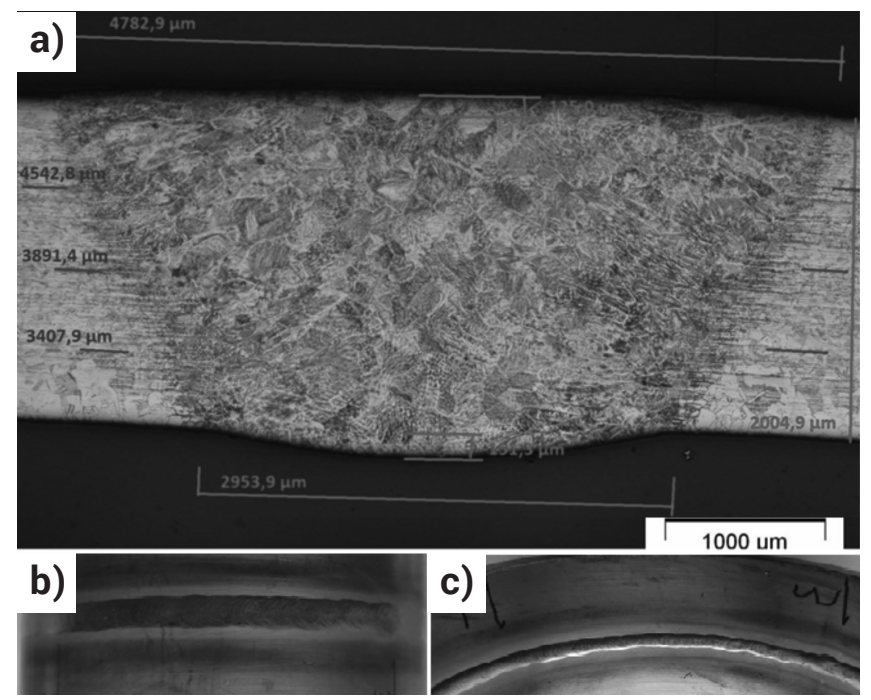

Rys. 6. Zdjęcie metalograficzne zgładu z sektora 2 złącza ze stali 304L wykonanego przy stężeniu tlenu resztkowego 6 ppm w gazie formującym. a) geometria i mikrostruktura spoiny, b) widok lica spoiny, c) widok grani spoiny

Fig. 6. Metallographic picture sector 2 of $304 \mathrm{~L}$ stainless steel weld formed at a concentration of 6 ppm of residual oxygen in the forming gas. a) geometry and microstructure of weld, b) weld face appearance, $c$ ) the appearance of the weld root

Grubość spawanego materiału wynosi około $2 \mathrm{~mm}$ i jest ona zgodna z klasą wykonania T3 wg PN-EN ISO 1127:1999. Lico spoiny jest szersze o $1,8 \mathrm{~mm}$ od grani. Wtopienie jest równomierne, liniowe i symetryczne, nie występuje charakterystyczny dla spawania w osłonie argonu kształt spoiny w postaci kielicha. Lico i grań spoiny mają niewielkie nadlewy wielkości odpowiednio 0,12 mm i 0,15 mm, mieszczą się 
one w dopuszczalnym zakresie podanym w ASME BPE-2007. $\mathrm{Na}$ długości spoiny widać niewielkie przesunięcie od osi wzdłużnej, spowodowane przez niedokładnie złożenie przedmiotów przy wykonaniu spoin montażowych. Przesunięcie to mieści się $w$ dopuszczalnym zakresie wg ASME BPE -2007. Szerokość spoiny jest zmienna nawet w obszarze jednego sektora parametrów spawania. Spoina ta ma tendencję do odchylania się od osi złącza na niewielkie wartości dopuszczalne w normie ASME BPE-2007. Ponadto prążki na licu są w kształcie łuków owalnych, rozmieszczonych na długości w sposób niesymetryczny i nierównomierny.

Lico spoiny wykonanej przy stężeniu 500 ppm tlenu resztkowego w gazie formującym (rys. 6b) w pierwszej części sektora 2 ma stałą szerokość ok. 4,4 mm. Linie graniczne lica spoiny są proste, co świadczy o stabilnym łuku elektrycznym, a także o braku odchyleń od osi złącza. W drugiej części sektora 2 odnotowano zwiększenie szerokości lica do $5 \mathrm{~mm}$ i jego odchylenie od osi złącza (widać je również poniżej, na zgładzie metalograficznym). Jest to tylko miejscowe odchylenie, po którym szerokości lica wraca do poprzedniej wartości. Lico spoiny jest płaskie, z widocznym przesadzeniem łączonych rur. Ślady po krystalizacji punktowych jeziorek spawalniczych są nieregularne. Grań spoiny (rys. 40c) w pierwszej części sektora 2 ma stałą szerokość jak w sektorze 1 - ok. 3,4 mm. Widoczne jest miejscowe odchylenie grani od osi złącza, które następuje w tym samym miejscu co odchylenie lica. W tym miejscu grań zmniejsza swoją szerokość do 3,2 mm. W dalszej części grań spoiny wraca do osi, zwiększając swoją szerokość. Przy zmianie parametrów z sektora 2 na sektor 3 następuje znaczne zmniejszenie szerokości grani oraz jej przebarwienia od koloru ciemno-niebieskiego (na początku sektora) przez fioletowo - purpurowy (na jego środku), do szarożółtego - brunatnego na końcu tego sektora. SWC ma znacznie mniejsze przebarwienie niż w sektorze 1 .

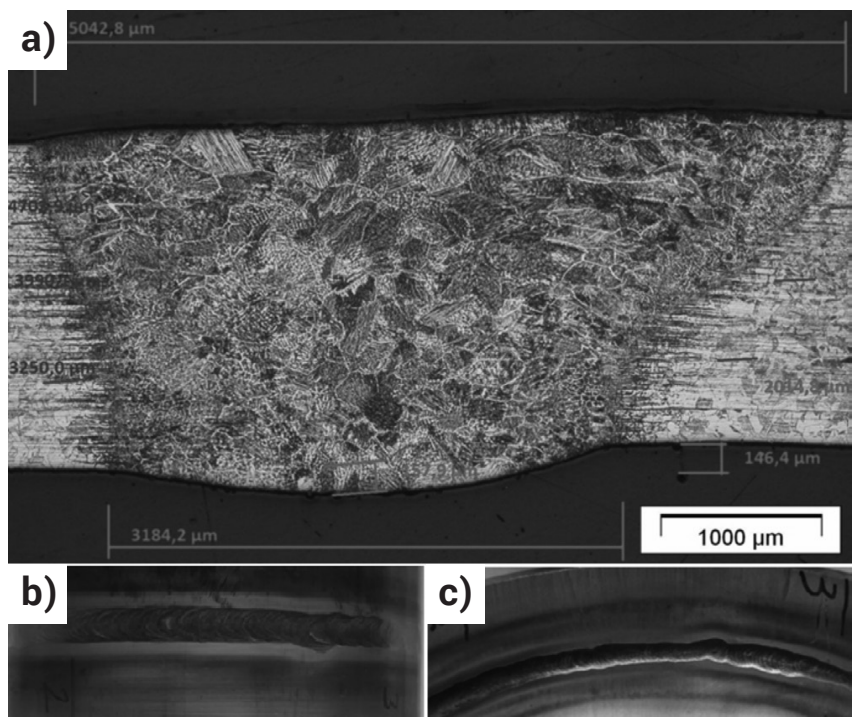

Rys. 7. Zdjęcie metalograficzne zgładu z sektora 2 złącza ze stali 304L wykonanego przy stężeniu tlenu resztkowego 500 ppm w gazie formującym. a) geometria i mikrostruktura spoiny, b) widok lica spoiny, c) widok grani spoiny

Fig. 7. Metallographic picture sector 2 of $304 \mathrm{~L}$ stainless steel weld formed at a concentration of $500 \mathrm{ppm}$ of residual oxygen in the forming gas. a) geometry and microstructure of weld, b) weld face appearance, $c$ ) the appearance of the weld root

Grubość spawanego materiału wynosi 2,01 mm i jest ona zgodna z klasą wykonania T3 wg PN-EN ISO 1127:1999. Badany wycinek spoiny (rys. 6a) został pobrany w miejscu odchylenia się spoiny, gdzie lico jest szersze o 1,9 mm od grani (jest to właśnie skutkiem odchylenia łuku od osi złącza). Również z tego powodu nierównomierne jest wtopienie, a przesunięcie lica w prawą stronę znacznie widoczne. Kształt wtopienia z obu stron jest charakterystyczny dla spawania w osłonie argonu, spoina ma wygląd kielicha. Należy również zauważyć znaczne przesunięcie łączonych ścianek o około 0,15 mm, co jednak mieści się w dopuszczalnym zakresie podanym w ASME BPE-2007. Od strony grani występuje nadlew wielkości 0,16 mm, mieści się on w dopuszczalnym zakresie. Biorąc pod uwagę przesunięcie ścianek łączonych elementów, lico spoiny można ocenić jako płaskie. Pomimo poprawności geometrycznej spoiny, jest ona niezgodna ze względu na występujące nadmierne przebarwienie grani i SWC (wg AWS D18.2:2009) powstałe w wyniku ooddziaływania tlenu na spoinę.

\section{Pomiary twardości w osi pionowej spoiny oraz w obszarze grani}

Pomiar twardości materiału spoiny od strony grani oraz w osi pionowej spoiny wykonano w celu wskazania wpływu stężenia tleniu w gazie formującym na właściwości mechaniczne. W przekroju poprzecznym złącza od strony grani, w każdym badanym miejscu materiału rodzimego, spoiny i strefy wpływu ciepła, wykonane zostały po 4 pomiary. Otrzymany wynik został uśredniony, a na wykresie zostało naniesione odchylenie standardowe od wartości średniej przy $95 \%$ poziomie ufności. Na wykresach rozkładu twardości przekroju złącza od strony grani dodatkowo oznaczono średnią twardość dla każdego z badanych sektorów.

$\mathrm{Na}$ rysunku 7 przedstawiony został rozkład twardości wykonany na przekroju poprzecznym złącza w sektorze 2, wykonanego ze stali 304L, przy stężeniu tlenu w gazie formującym na poziomie 6 ppm. Zakres zmiany twardości jest stosunkowo niewielki, przy dość dużych wartościach odchylenia standardowego, co jest charakterystyczne dla struktury pierwotnej.

$\mathrm{Na}$ rysunku 8 widoczne jest zmniejszenie twardości w SWC spowodowane rekrystalizacją. Twardość w SWC na obwodzie spoiny ulega znacznym zmianom. Zaobserwowano ogólne wystąpienie mniejszych spadków twardości w SWC w sektorze 3. SWC dla stali 304L charakteryzuje się możliwością wystąpienia zwiększonej ilości ferrytu w strefie przy linii wtopienia. Zwiększenie jego ilości jest skutkiem szybkiego stygnięcia, co uniemożliwia pełną jego przemianę w austenit. Odchylenie standardowe dla większości pomiarów materiału rodzimego jest mniejsze, niż przy pomiarach SWC i spoiny, ponieważ materiał ma drobniejszą, jednolitą strukturę pasmową po walcowaniu.

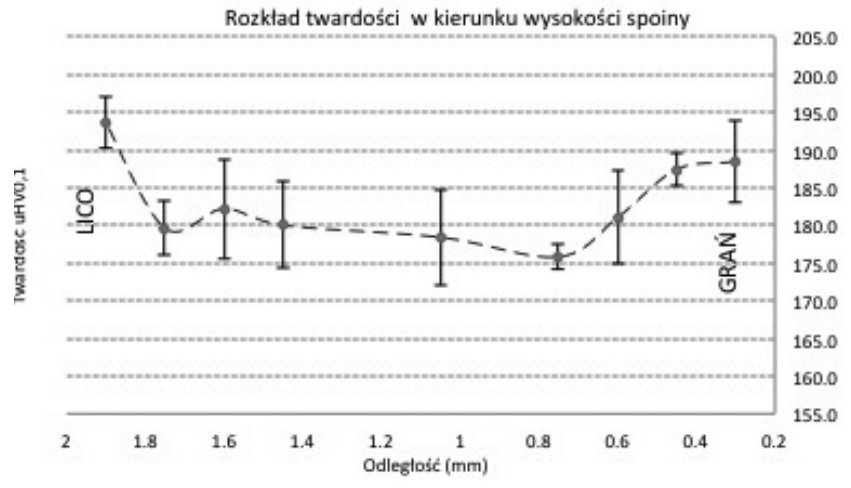

Rys. 8. Rozkład twardości w przekroju poprzecznym złącza licograń dla połączenia ze stali 304L wykonanego przy 6ppm zawartości tlenu w gazie formującym

Fig. 8. Hardness distribution in cross-section in face-root system obtained with 6ppm oxygen in forming gas 


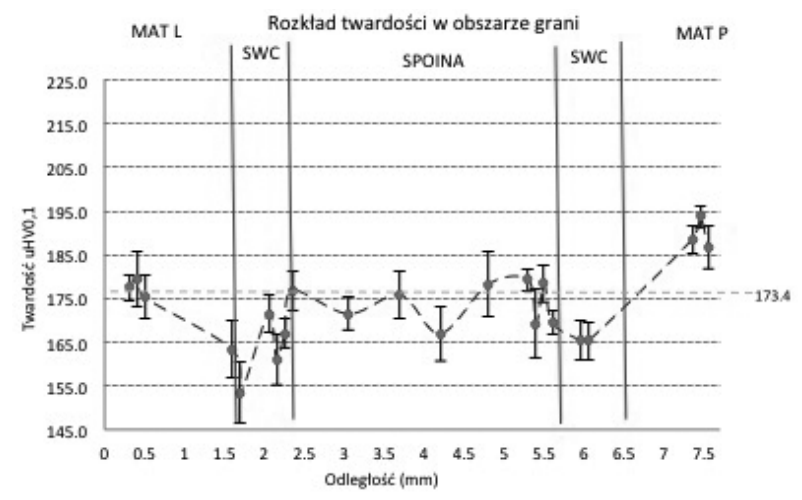

Rys. 9. Rozkład twardości w przekroju poprzecznym złącza w obszarze grań dla połączenia ze stali 304L wykonanego przy 6 ppm zawartości tlenu w gazie formującym

Fig. 9. Hardness distribution in cross-section root area, obtained with $6 \mathrm{ppm}$ oxygen in forming gas

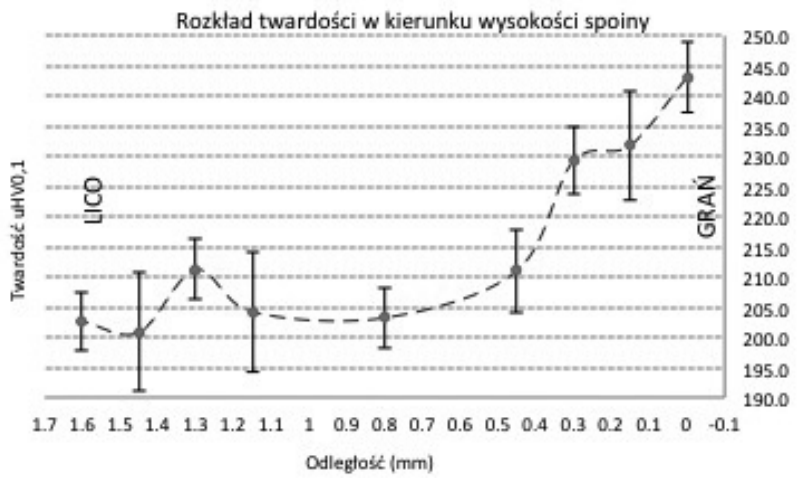

Rys. 10. Rozkład twardości w przekroju poprzecznym złącza licograń dla połączenia ze stali 304L wykonanego przy 500 ppm zawartości tlenu w gazie formującym

Fig. 10. Hardness distribution in cross-section in face-root system obtained with 500 ppm oxygen in forming gas

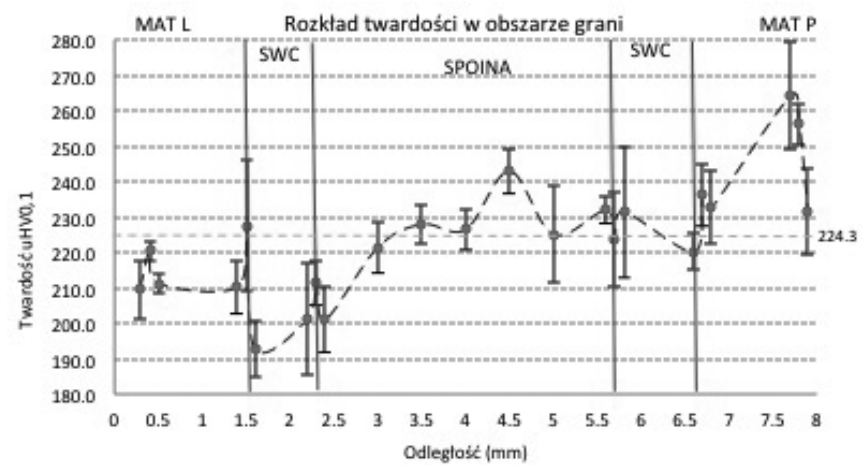

Rys. 11. Rozkład twardości w przekroju poprzecznym złącza w obszarze grań dla połączenia ze stali 304L wykonanego przy 500 ppm zawartości tlenu w gazie formującym

Fig. 11. Hardness distribution in cross-section root area, obtained with 500 ppm oxygen in forming gas

Na rysunkach $7 \div 10$ przedstawiono rozkłady twardości, z których wynika, że wzrost stężenia tlenu z 6 do 500 ppm w gazie formującym spowodował duży wzrost twardości w obszarze grani tj. o około $50 \mu \mathrm{HV}$.

\section{Podsumowanie i wnioski:}

- Złącze wykonane z niższym stężeniem tlenu w gazie formującym (6 ppm). Charakteryzuje się większą jednorodnością twardości w przekroju poprzecznym.

- Niskie stężenie tlenu w gazie formującym przy wykonywaniu złączy ze stali 304L powoduje, iż nie powstaje utwardzenie spoiny będące efektem zwiększonego udziału faz tlenkowych od strony grani, które zwiększa niejednorodność twardości i może mięć wpływ na wytrzymałość zmęczeniową złącza.

- Należy bezwzględnie przestrzegać zasad właściwego wypełnienia rurociągu gazem formującym i zabezpieczać miejsca spawane przed dostępem powietrza, zapewni to poprawność wykonanych złączy.

- Repasywacja nadmiernie utlenionej stali może przywrócić odporność korozyjną utlenionej powierzchni, natomiast utwardzenie obszaru grani powstałe poprzez nadmierne utlenienie pozostaje.

\section{Literatura}

[1] T. Chmielewski: Projektowanie procesów technologicznych - spawalnictwo Oficyna Wydawnicza Politechniki Warszawskiej, Warszawa, 2013.

[2] M. Gucwa, R. Bęczkowski, M. Stefański: Spawanie orbitale wężownic ze stali VM12-SHC, Przegląd Spawalnictwa, vol. 87(10), s.120-123, 2015.

[3] A. Kolasa, P. Cegielski, A. Oneksiak Nowa głowica do orbitalnego doczołowego spawania rur metodą TIG, Przegląd Spawalnictwa, vol. 86(3), s. 32-38, 2014.

[4] G. Rogalski, J. Łabanowski, D. Fydrych, A. Świerczyńska: Wpływ obróbki cieplnej na właściwości spawanych austenitycznych rur wymienników ciepła, Przegląd Spawalnictwa, vol. 86(6), s. 24-31, 2014.

[5] K. Ferenc, J. Ferenc: Spawalnicze gazy osłonowe i palne, Wydawnictwa Naukowo-Techniczne, Warszawa 2005

[6] J. Górecki, T. Chmielewski, A. Kolasa: Automatyczne spawanie łukiem krytym elementów rurociągów ze stali nierdzewnej 347, Spajanie Metali i Tworzyw w Praktyce 11(4), s. 16-19, 2005.
[7] M. Węglowski, T. Chmielewski, K. Kudła: Ocena wydajności spawania niskoenergetycznego procesu SpeedRoot w pozycji PG, Przegląd Spawalnictwa, vol. 83(12), s. 26-30, 2011.

[8] T. Chmielewski, M. Węglowski, K. Kudła: Spawanie w pozycji PF metodą MMA z wykorzystaniem nowej funkcji UP w zasilaczach inwertorowych zbudowanych w technice MICOR, Przegląd Spawalnictwa, vol. 86(9), s. $45-49,2014$

[9] AWS D18.2:2009, Guide to Weld Discoloration Levels on Inside of Austenitic Stainless Steel Tube, American Welding Society 2009.

[10] K. Kimbrel: Determining Acceptable Levels of Weld Discoloration on Mechanically Polished and Electropolished Stainless Steel Surface, [w:] Pharmaceutical Engineering, vol. 31 no. 6, December 2011

[11] E. Tasak: Metalurgia Spawania, Wydawnictwo "Jak" Andrzej Choczewski, Kraków 2008. 